\title{
Peran Komunitas Red Batik Dalam Mendukung Kota Solo Sebagai Kota Kreatif
}

Muhammad Nur Indra Wicaksono ${ }^{\mathrm{a}, 1}$, I Made Adikampana $\mathrm{a}^{\mathrm{a}, 2}$

1goowicaksono@gmail.com, 2adikampana@unud.ac.id

aProgram Studi Sarjana Destinasi Pariwisata, Fakultas Pariwisata, Universitas Udayana, Jl. Dr. R. Goris, Denpasar, Bali 80232 Indonesia

\section{Abstract}

Solo City has so many communities with different aspects of value from one another. The Red Batik community is chosen based on its credibility and is one of the most productive communities in Solo City. This study aims to determine the establishment of the Red Batik Community, as well as identify and explain the role of the Red Batik Community in supporting the City of Solo as a Creative City.

The research methodology used in this study is research with in-depth interview techniques, observation, literature study and documentation. In addition to using the concept of community-based tourism, role concepts and creative city concepts to review existing problems.

The Red Batik community becomes a space for informal education by providing a forum for people who want to get involved or engage in industry and creative activities, especially costumes and carnivals, preserve traditional markets that are characteristic of Solo City, and hold interesting shows for tourists. As a city full of cultural values, Solo City is an attractive place for tourists to visit.

Keywords: Creative City, Roles, Community Based Tourism, Red Batik Solo.

\section{PENDAHULUAN}

Salah satu strategi untuk meningkatkan kualitas hidup dalam masyarakat ialah dengan cara pengembangan pariwisata. Pariwisata sebagai sebuah industri yang mampu membentuk pengaruh luas antara lain social, ekonomi, budaya maupun lingkungan. Dampak dari pengaruh tersebut tidak hanya dialami oleh pelaku kegiatan, produsen atau konsumen saja, tetapi juga masyarakat sekitarnya.

Kota Solo memiliki beberapa slogan (tagline) sebagai salah satu upaya guna mendatangkan wisatawan, baik wisatawan domestik ataupun wisatawan mancanegara, untuk berkunjung dan berwisata di Kota Solo. Slogan (tagline) tersebut antara lain: "Solo, The Spirit of Java" yang berarti 'Solo Adalah Jiwanya Jawa', kemudian ada 'Kota Budaya', 'Kota Batik', dan 'Kota Seni Pertunjukan'. Namun pada tahun 2012, dibawah pimpinan walikota Joko Widodo, Kota Solo menggelorakan slogan (tagline) baru dengan nama "Solo Kota Kreatif". Hal ini tentunya mengisyaratkan pemerintah untuk meningkatkan kesejahteraan masyarakat dengan program pembangunan kreatif.

Kota kreatif ialah sebuah kota yang mempunyai beragam "ekosistem kreatif", sehingga dapat menjadi penggerak sumber daya manusia agar memiliki kemampuan di dalam menciptakan hal baru. Dari pandangan tersebut jelas bahwa dengan adanya kota kreatif, pariwisata tidak lagi dipandang bahwa pelaku pariwisata adalah investor atau pemerintah saja melainkan masyarakat pun juga mampu sebagai penggerak ataupun pembentuk destinasi pariwisata. Kemudian UNESCO mengembangkan konsep kota kreatif dari inilah terbentuk Indonesia Creative Cities Network dalam konferensi kota kreatif indonesia untuk pertama kalinya terselenggara di Kota Solo pada Okbober tahun 2015 kemarin.

Komunitas memiliki peran penting dalam pembangunan pariwisata, dilihat dalam CBT (Community Based Tourism). Mengembangkan sebuah destinasi wisata dengan memberdayakan masyarakat lokal (komunitas), untuk turut serta merencanakan, mengelola hingga memberikan suara keputusan dalam pembangunan. Sehingga pemberdayaan komunitas lebih ditekankan untuk memahami nilai dan aset yang dimiliki, seperti adatistiadat, masakan, budaya, gaya hidup dan lainlain. Dengan demikian, dalam mendukung Kota Solo sebagai kota kreatif, komunitas dengan mandiri memobilisasi nilai dan asset menjadi sebuah daya tarik pengalaman berwisata.

Kota Solo memiliki begitu banyak komunitas dengan aspek nilai yang berbeda antara satu dengan yang lainnya. Pemilihan komunitas sebagai pokok pembahasan sangat penting menilik waktu dalam penelitian. Komunitas Red Batik dipilih berdasarkan kredibilitasnya, dimana komunitas ini telah tampil di berbagai acara atau event baik skala nasional maupun internasional dan merupakan salah satu komunitas yang paling produktif di Kota Solo, karena komunitas ini mampu bertahan dan terus berkarya. Selain itu, 
komunitas ini telah memberikan banyak pelatihan baik di Kota Solo maupun di kotakota lainnya dan menyebarkan sebuah paham ideologi baru bahwa pasar tradisional mampu memberikan suatu karya, mampu diolah menjadi sebuah kreativitas yang berkelas. Sehingga hal ini menarik penulis untuk mengidentifikasi serta memaparkan peran Komunitas Red Batik dalam mendukung Kota Solo sebagai kota kreatif.

\section{TINJAUAN PUSTAKA}

\subsection{Telaah Hasil Penelitian Sebelumnya}

Telaah penelitian pertama yaitu oleh Setyawan (2013) yang berjudul "Pengembangan Kota Solo Sebagai Kota Wisata Kreatif". Dalam penelitian ini dijelaskan faktorfaktor pendorong pengembangan wisata kreatif Kota Solo, upaya pengembangan Kota Solo sebagai kota wisata kreatif, serta kendala yang dihadapi dan solusi yang harus dilakukan.

Telaah penelitian selanjutnya yaitu oleh Yulianto Wahyu Saputro (2015) yang berjudul "Tahapan Perwujudan Kota Surakarta Sebagai Kota Kreatif Desain". Dalam penelitian ini dijelaskan bagaimana cara yang dilakukan untuk mewujudkan Kota Surakarta sebagai Kota Kreatif kriteria Desain serta menunjukkan potensi budaya lokal dan kreatifitas.

\subsection{Landasan Teori dan Konsep}

1. Konsep Komunitas.

Menurut Saunders (1982) komunitas adalah tempat berkumpulnya orang dan sistem sosial. Terdiri dari lingkungan fisik dan sosial, kumpulan orang terdiri gambaran populasi yang berisikan jumlah, tingkat pendidikan dan lainnya. Sistem sosial menyangkut interaksi individu, keluarga, kelompok maupun masyarakat. Sedangkan menurut Soedjono Soekanto (1992), komunitas merujuk bagian masyarakat yang bertempat tinggal dalam suatu wilayah dengan batasan tertentu, dan interaksi yang lebih besar dari anggotanya jika dibandingkan dengan penduduk luar wilayah menjadi sebuah dasarnya.

\section{Konsep Peran.}

Hari Soegiman (1990:2) mengatakan bahwa peran ialah kehadiran di dalam menentukan sebuah proses keberlangsungan. Sementara itu Soleman B. Taneko (1986: 23) dalam Alvin L. Bertrand, mengatakan bahwa peran adalah sebuah pola tingkah laku yang menjadi harapan dari seseorang yang memiliki kedudukan ataupun staus tertentu. Kemudian, Dougherty \& Pritchard tahun 1985 (2003: 56) menjelaskan relevansi peran akan bergantungan pada penekanan peran itu sendiri oleh para pengamat maupun ahli, pada produk ataupun outcome yang dihasilkan. Struktur organisasi dan strategi juga mempengaruhi presepsi peran atau role perception. (Kahn, et al., 1964; Oswald, Mossholder, \& Harris, 1997, 2003: 58)

\section{Konsep Daya Tarik Wisata.}

Berdasarkan Undang-Undang Republik Indonesia No. 10 Tahun 2009, daya tarik wisata dijelaskan sebagai sesuatu yang memiliki keanekaragaman kekayaan alam, budaya mapun hasil buatan manusia, keunikan serta kemudahan yang menjadi tujuan kunjungan wisatawan. Menurut Oka A. Yoeti dalam bukunya "Pengantar Ilmu Pariwisata" tahun 1985 menyatakan daya tarik wisata atau tourist attraction, adalah segala sesuatu yang menjadi daya tarik bagi orang untuk mengunjungi suatu daerah tertentu. Selain itu juga menurut Nyoman S. Pendit dalam bukunya "Ilmu Pariwisata" tahun 1994 mendefinisikan daya tarik wisata sebagai segala sesuatu yang menarik dan bernilai untuk dikunjungi dan dilihat.

\section{Konsep Pariwisata Berbasis Masyarakat}

Community Based Tourism (CBT) sebagai suatu konsep yang menjelaskan peranan komunitas dalam pembangunan pariwisata. CBT membahas mengenai bagaimana mengembangkan sebuah destinasi wisata dengan memberdayakan masyarakat (komunitas), dimana (komunitas) ikut berpartisipasi dalam mengelola, merencanakan dan memberikan suara berupa keputusan pembangunan. Dalam CBT, konsep ini menitikberatkan memberdayakan komunitas menjadi memahami aset dan nilai yang dimiliki, seperti gaya hidup, kuliner khas, budaya, adatistiadat. Komunitas dengan mandirinya memobilisasi nilai dan aset tersebut sebagai daya tarik wisatawan. Melalui CBT, setiap personal di dalam komunitas digerakkan menjadi bagian dalam ekonomi pariwisata, sehingga setiap orang dibekali keterampilan untuk mengembangkan. Suansuri (2003) CBT memiliki beberap prinsip sebagai berikut: 
a. Mengenali dan mendukung dengan mempromosikan kepemilikan masyarakat di dalam pariwisata.

b. Anggota dilibatkan dalam setiap tahap mengembangkan pariwisata berbagai aspek.

c. Kebanggaan pada komunitas yang bersangkutan dipromosikan.

d. Memberikan jaminan keberlanjutan lingkungan hidup.

e. Meningkatkan kualitas hidup.

f. Menjaga keunikan maupun budaya yang ada dalam masyarakat.

g. Mengembangkan pembelajaran lintas budaya.

h. Respek terhadap perbedaan martabat maupun budaya manusia.

i. Menyalurkan manfaat serta keuntungan secara merata kepada masyarakat.

j. Menyumbangkan pendapatan dengan presentase tertentu yang didapat untuk proyek pengembangan.

k. Mengedepankan keaslian hubungan antara masyarakat dengan lingkungan.

Memalui penjabaran diatas, hal tersebut sangat berbeda dengan pendekatan lain, karena komunitas sebagai aktor utama dalam mengembangkan kepariwisataan untuk menaikkan kualitas standar hidup masyarakat. Maka dari itu, CBT menjadi pariwisata yang sadar akan keberlangsungan social, budaya maupun lingungan. Komunitas membantu pengunjung wisata untuk sadar dan belajar tentang masyarakat yang ada.

\section{Konsep Kota Kreatif}

Secara epistemologis, kreatif memiliki makna suatu kemampuan untuk menciptakan sesuatu yang baru, tetapi memerlukan "ekosistem pendorong" guna melakukannya dan bersifat individual. Berdasarkan pengertian itu, kota kreatif ialah kota yang mempunyai "ekosistem kreatif" yang dapat memicu sumber daya manusia (individu) sebagai penggerak sebuah kota untuk mempunyai keahlian membuat sesuatu yang baru. Istilah ini pertama kali dikenalkan oleh Charles Landry di dalam bukunya yang berjudul "The Creative City; A toolkit for Urban Innovators" pada tahun 1995. UNESCO turut mengembangkan konsep kota kreatif yang menjadi bagian dalam program Creative City Network. Secara konseptual, kota kreatif perlu memiliki sinergitas antara akademisi, masyarakat, pemerintah dan pelaku usaha. Konsep ini dikenal pula dengan nama Quadro Helix.

\section{METODE PENELITIAN}

Penelitian dilaksanakan di Kota Solo, Provinsi Jawa Tengah. Objek penelitian Komunitas Red Batik yang berada di Kota Solo. Dimana lebih tepatnya beralamat di Jalan Jawa 18 Timuran, Banjarsari, Solo, Jawa Tengah. Deskriptif kualitatif digunakan sebagai metodologi jenis data dan data primer digunakan sebagai sumber data berkaitan dengan peran komunitas red batik dalam mendukung solo sebagai kota kreatif dan data sekunder yaitu data sejarah berdirinya serta agenda yang telah dilaksanakan/dicapai komunitas red batik solo. Pengumpulan data dilaksanakan dengan menggunakan observasi, studi literasi, wawancara dengan informan serta dokumentasi. Menganalisa data berawal dengan mengumpulkan data, dilanjutkan dengan mereduksi data, kemudian menyajikan data lalu tahap akhir ialah conclusion atau verification data.

\section{HASIL DAN PEMBAHASAN}

\subsection{Gambaran Umum Komunitas Red Batik}

Komunitas Red Batik Solo berdiri pada tanggal 12 februari 2011, kata "red" bisa diartikan dalam bahasa inggris yang berarti "merah", yang memiliki makna tentang "sebuah keberanian" dan juga "red" yang merupakan singkatan dari kata dalam bahasa jawa yakni " Rekso Estining Dumadi" yang berarti "merawat bumi dan kehidupan". Komunitas ini di ketuai atau di koordinasi oleh Bapak Heru Prasetya, beliau merupakan lulusan atau alumni dari Sekolah Tinggi Seni Indonesia atau yang saat ini bernama ISI (Institut Seni Indonesia) Surakarta dan merupakan salah satu penggiat seni di Kota Solo.

Komunitas Red Batik merupakan komunitas yang bergerak dibidang kostum dan karnaval dan merupakan satu-satunya komunitas di Kota Solo yang bergerak di bidang ini. Dalam berkreasi, komunitas ini menggunakan pasar tradisional sebagai pokok utamanya. "Jati diri sebuah kota itu ya pasar tradisional itu. Kota Solo terlihat beda karena ada pasar tradisionalnya, dan setiap pasar di solo punya keunikan masing-masing. Namun saat ini keberadaan pasar tradisional mulai tergerus oleh mall, hotel dan sebagainya, dan 
saya mencoba melestarikan pasar tradisional melalui kegiatan-kegiatan yang kreatif. Yakni dengan pembuatan kostum-kostum karnaval dari bahan-bahan alam yang di dapatkan di pasar tradisional Kota Solo", terang Heru Prasetya. Sehingga kostum-kostum yang mereka buat berasal dari bahan yang terdapat di pasar, mulai dari lontar, batang maupun kulit bawang, berbagai macam biji-bijian, pakis dan sebagainya. Komunitas Red Batik tidak hanya bertaraf nasional namun telah mampu menembus skala internasional, hal ini dibuktikan dengan seringnya mereka mengisi atau menjadi bagian dari festival di berbagai negara.

\subsection{Tujuan Berdirinya Komunitas Red Batik}

Berdiri sejak tahun 2011, berarti sudah selama tujuh tahun Komunitas Red Batik ini terus berkarya. Komunitas ini memiliki visi "Melestarikan nilai-nilai dan eksistensi kearifan lokal indonesia (Indonesian Heritage) dalam ekspresi karnaval", dan misi "Menumbuhkembangkan kesadaran kaum muda Kota Solo dan kota-kota lainnya di Indonesia mencintai kekayaan ragam hayati Indonesia" dan "Mengoptimalkan individuindividu yang tergabung dalam Red Batik sebagai desainer kostum karnaval yang mandiri dan handal". Melahirkan generasi perancang atau individu yang mandiri tidaklah mudah, terang Heru Prasetya. Beliau juga menjelaskan bahwa, ada beberapa anggota yang tidak mampu berproses dan beberapa terus menjalani proses. Bagi mereka yang tidak mampu mereka keluar dengan sendirinya, sedangkan yang mampu mereka terus berproses dan bertahan. Nantinya jika tidak menjadi seorang desainer, diharapkan mereka menjadi orang yang kreatif, jika menjadi seorang guru maka menjadi guru yang kreatif, jika seorang dokter maka dokter yang kreatif, dan sebagainya.

Komunitas Red Batik merupakan ruang belajar informal bagi siapapun, yang nantinya diharapkan menjadi manusia yang kreatif dan mandiri. Dengan demikian diharapkan mereka akan menjadi individu mandiri dan terus berkarya dengan kreatif sehingga selain berpengaruh terhadap diri-sendiri, dimana nantinya mampu menciptakan sesuatu atau membentuk kegiatan yang unik dan kreatif bagi Kota Solo, sehingga dengan adanya regenerasi tersebut mampu terus terjadi pembaharuan kegiatan-kegiatan ataupun adanya sebuah event menarik agar wisatawan terus datang ke Kota Solo. Selain itu, kearifan lokal seperti batik dan pasar tradisional dapat terus terjaga dengan baik. Dengan adanya kegiatan-kegiatan kreatif yang turut melibatkan pasar tradisional, maka nantinya pasar tradisional bisa menjadi suatu destinasi wisata yang layak untuk dikunjungi di Kota Solo. Hal ini tentunya juga harus ditunjang dengan pemberian fasilitas yang baik, sehingga wisatawan datang ke pasar tradisional dalam keadaan nyaman dan aman.

\subsection{Peran Komunitas Red Batik Dalam Mendukung Solo Sebagai Kota Kreatif}

Sebagai kota yang sarat dengan nilai budaya, Kota Solo menjadi menarik untuk dikunjungi wisatawan, oleh karena itu pengembangan wisata melalui wisata kreatif akan sangat diperlukan guna kemajuan pariwisata di Kota Solo. Karena jika hanya mengandalkan bangunan bersejarah, pariwisata di Kota Solo tidak akan mengalami peningkatan atau akan stagnan. Dengan demikian pengembangan wisata kreatif merupakan jalan terbaik untuk memajukan pariwisata Kota Solo dengan daya dukung yang telah ada, seperti kerajinan, budaya maupun kesenian.

Hermantoro (2011), menjelaskan pariwisata dengan kreativitas ialah suatu kepariwisataan dengan terlibatnya komunitas lokal sebagai sumber dan terlibat proses kreativitas dalam kunjungan wisata. Bisa dikatakan bahwa pariwisata kreatif adalah konsep yang keberadaan komunitas menjadi tanggung jawab utama. Hal senada diungkapkan juga oleh koordinator Komunitas Red Batik Solo, Heru Prasetya, "kota yang kreatif itu kota yang didukung oleh komunitasnya, jadi jangan ngomong menjadi kota kreatif kalau tidak ada komunitasnya". Dengan demikian komunitas menjadi unsur penting dalam memajukan pariwisata di Kota Solo. sebagian atraksi wisata ataupun acara (event) yang terselenggara di Kota Solo diprakarsai oleh komunitas.

Heru menambahkan bahwa, komunitas bergerak atas kemandirian bukan atas pemerintah, jadi memang kalau ingin menjadi kota kreatif ya harusnya memang komunitas itu harus benar-benar di lahirkan, di bentuk, maupun di dorong, dan di solo banyak sekali komunitas-komunitasnya dan itu menjadi 
bagian penting dari Kota Solo karena tanpa itu ya tidak ada apa-apanya, terangnya.

Pandangan tersebut jelas bahwa dengan adanya kota kreatif, pariwisata tidak lagi dipandang bahwa pelaku pariwisata adalah investor atau pemerintah saja melainkan masyarakat pun juga mampu sebagai penggerak ataupun pembentuk destinasi pariwisata. Pada konferensi kota kreatif yang pertama tersebut dikeluarkanlah 10 prinsip kota kreatif yang telah dijabarkan sebelumnya. Dengan ini akan dilakukan perbandingan antara 10 prinsip kota kreatif dengan peran ataupun data Komunitas Red Batik Solo yang dapat dilihat dalam tabel 1 dibawah ini.

Berdasarkan data dalam tabel tersebut, 6 dari 10 prinsip kota kreatif, komunitas Red Batik memiliki peran atau memiliki pengaruh terhadap Kota Solo untuk menjadi kota kreatif. Dan tidak dapat dipungkiri bahwa nantinya Komunitas Red Batik juga turut andil dalam bagian 4 dari 10 prinsip yang tergolong pemerintah kota. Komunitas memiliki pengaruh maupun peran dalam memajukan pariwisata Kota Solo, tidak hanya sebatas Komunitas Red Batik saja namun komunitaskomunitas lainpun juga memiliki peran dalam mewujudkan kemajuan kepariwisata Kota Solo dan mendukung Kota Solo Sebagai kota kreatif.

Tabel 1: Peran Komunitas Red Batik Dalam Mewujudkan Kota Kreatif

\begin{tabular}{|c|c|c|}
\hline & $\begin{array}{l}10 \text { Prinsip Kota } \\
\text { Kreatif }\end{array}$ & $\begin{array}{l}\text { Komunitas } \\
\text { Batik }\end{array}$ \\
\hline 1. & $\begin{array}{l}\text { Kota yang } \\
\text { menjunjung tinggi } \\
\text { keanekaragaman } \\
\text { sosial budaya. } \\
\text { Kota yang terbuka } \\
\text { menjunjung tinggi } \\
\text { nilai kemanusiaan, } \\
\text { dan menumbuh } \\
\text { kembangkan } \\
\text { semangat } \\
\text { kebersamaan, } \\
\text { solidaritas dan } \\
\text { perdamaian. }\end{array}$ & $\begin{array}{l}\text { Di dalam komunitas } \\
\text { ini menjunjung } \\
\text { kebersamaan dan } \\
\text { keberagaman sosial } \\
\text { budaya. Anggota } \\
\text { disini memiliki } \\
\text { berbagai yang tidak } \\
\text { sama, mahasiswa } \\
\text { dengan berbagai } \\
\text { bidang ilmu, seperti } \\
\text { ekonomi, hukum, } \\
\text { desain grafis, dan } \\
\text { lain-lain, maupun } \\
\text { mereka yang masih } \\
\text { dibangku sekolah } \\
\text { dasar, SMP dan SMA. } \\
\text { Dalam memuliakan } \\
\text { nilai kemanusiaan, } \\
\text { Red Batik pernah } \\
\text { mengajak anak-anak }\end{array}$ \\
\hline
\end{tabular}

\begin{tabular}{|c|c|}
\hline & $\begin{array}{l}\text { dari YPAC Solo untuk } \\
\text { turut berpartisipasi } \\
\text { dalam agenda } \\
\text { Vastenburg Carnival } \\
\text { tahun 2014. Sehingga } \\
\text { Red Batik turut } \\
\text { berperan sebagai } \\
\text { komunitas yang } \\
\text { menyatukan } \\
\text { keberagaman dan } \\
\text { mempererat } \\
\text { hubungan sosial } \\
\text { dalam satu wadah } \\
\text { dengan tujuan yang } \\
\text { sama serta } \\
\text { memuliakan nilai } \\
\text { kemanusiaan tanpa } \\
\text { membeda-bedakan } \\
\text { dari kondisi fisik } \\
\text { maupun kejiwaan } \\
\text { untuk turut berperan } \\
\text { dalam sebuah karya } \\
\text { dan kreatifitas. }\end{array}$ \\
\hline $\begin{array}{l}\text { 3. Kota yang dapat } \\
\text { menjaga hak asasi } \\
\text { manusia yang } \\
\text { membela ekonomi, } \\
\text { sosial serta budaya } \\
\text { masyarakatnya. }\end{array}$ & $\begin{array}{l}\text { Red Batik } \\
\text { menggunakan pasar } \\
\text { tradisional sebagai } \\
\text { kekuatan utama } \\
\text { dalam berkarya. } \\
\text { Bahan-bahan yang } \\
\text { digunakan } \\
\text { merupakan bahan } \\
\text { alam yang } \\
\text { didapatkan dari } \\
\text { pasar tradisional. } \\
\text { Sehubungan dengan } \\
\text { perkembangan } \\
\text { zaman, masyarakat } \\
\text { mulai menjadikan } \\
\text { modernitas sebagai } \\
\text { gaya hidup, dan } \\
\text { pasar tradisional } \\
\text { terpinggirkan. } \\
\text { Dengan ini Red Batik } \\
\text { turut menjaga atau } \\
\text { turut melestarikan } \\
\text { pasar tradisional, } \\
\text { dimana membantu } \\
\text { ekonomi, dan } \\
\text { menjaga hubungan } \\
\text { sosial dan budaya } \\
\text { masyarakat Kota } \\
\text { Solo. }\end{array}$ \\
\hline $\begin{array}{ll}\text { 4. } & \text { Kota yang } \\
& \text { memuliakan } \\
& \text { kreativitas } \\
& \text { masyarakatnya, }\end{array}$ & $\begin{array}{l}\text { Komunitas ini } \\
\text { mengajak untuk } \\
\text { berkarya, menjaga } \\
\text { budaya lokal, dan } \\
\text { turut mengasah }\end{array}$ \\
\hline
\end{tabular}




\begin{tabular}{|c|c|c|}
\hline & $\begin{array}{l}\text { mengembangkan } \\
\text { dan memanfaatkan } \\
\text { kecerdasan, } \\
\text { kearifan lokal, } \\
\text { keterampilan, daya } \\
\text { cipta dan } \\
\text { kemampuan nalar. }\end{array}$ & $\begin{array}{l}\text { keterampilan, daya } \\
\text { cipta maupun } \\
\text { kemampuan nalar. } \\
\text { Denga adanya } \\
\text { kegiatan workshop, } \\
\text { pelatihan, guna untuk } \\
\text { menciptakan sebuah } \\
\text { gagasan, ide dalam } \\
\text { berkarya dan dimana } \\
\text { nantinya jika telah } \\
\text { selesai bisa } \\
\text { dipentaskan, menjadi } \\
\text { suguhan yang } \\
\text { menarik. }\end{array}$ \\
\hline & $\begin{array}{l}\text { Kota tumbuh } \\
\text { bersama } \\
\text { lingkungan lestari, } \\
\text { yang hidup sejalan } \\
\text { dengan dinamika } \\
\text { lingkungan dan } \\
\text { alam sekitar. }\end{array}$ & $\begin{array}{l}\text { Berkarya dengan } \\
\text { menggunakan bahan } \\
\text { alami maupun bahan } \\
\text { yang tidak terpakai, } \\
\text { seperti rotan, karung } \\
\text { goni, mahoni, pakis } \\
\text { bahkan sisa batang } \\
\text { bawang yang sudah } \\
\text { tidak terpakai bisa } \\
\text { dimanfaatkan, } \\
\text { menjadikan } \\
\text { komunitas ini turut } \\
\text { menjaga lingkungan, } \\
\text { mengajarkan untuk } \\
\text { hidup mandiri, } \\
\text { menjaga alam, serta } \\
\text { pemaksimalan } \\
\text { pemanfaatan sebuah } \\
\text { barang. }\end{array}$ \\
\hline & $\begin{array}{l}\text { Kota yang } \\
\text { memelihara } \\
\text { kearifan sejarah. }\end{array}$ & $\begin{array}{l}\text { Komunitas Red Batik } \\
\text { turut memelihara } \\
\text { kearifan sejarah Kota } \\
\text { Solo. Dalam } \\
\text { perwujudannya, } \\
\text { pasar-pasar } \\
\text { tradisional di Kota } \\
\text { Solo merupakan } \\
\text { bukti sejarah yang } \\
\text { masih berfungsi dan } \\
\text { menjadi sarana } \\
\text { masyarakat Kota } \\
\text { Solo. Selain itu } \\
\text { komunitas ini juga } \\
\text { memelihara batik, } \\
\text { dengan konsep dan } \\
\text { tatanan yang unik, } \\
\text { batik mampu } \\
\text { berkembang dan } \\
\text { menjadi tontonan } \\
\text { yang luar biasa. Dan } \\
\text { ini mampu } \\
\text { memberikan dampak } \\
\text { terhadap pengrajin }\end{array}$ \\
\hline
\end{tabular}

\begin{tabular}{|l|l|}
\hline & $\begin{array}{l}\text { maupun penjual } \\
\text { batik. }\end{array}$ \\
\hline 7. $\begin{array}{l}\text { Kota yang dikelola } \\
\text { secara transparan, } \\
\text { adil, dan jujur yang } \\
\text { mengedepankan } \\
\text { nilai gotong-royong } \\
\text { dan kolaborasi. }\end{array}$ & KOTA) \\
(PEMERINTAH \\
8. $\begin{array}{l}\text { Kota dapat } \\
\text { memenuhi dasar } \\
\text { kebutuhan } \\
\text { masyarakat. }\end{array}$ & \\
\hline $\begin{array}{l}\text { Kota yang } \\
\text { memanfaatkan } \\
\text { energi terbarukan, } \\
\text { guna memenuhi } \\
\text { kebutuhan energi } \\
\text { secara bijaksana } \\
\text { serta } \\
\text { berkelanjutan. } \\
\text { 10. Kota yang dapat } \\
\text { menyediakan } \\
\text { fasilitas layak. } \\
\text { Termasuk untuk } \\
\text { kelompok rek } \\
\text { masyarakat rentan } \\
\text { dan berkebutuhan } \\
\text { khusus. }\end{array}$ \\
\end{tabular}

Sumber: penelitian (2016)

Komunitas Red Batik berperan terhadap perkembangan Kota Solo, dilihat dari segi sosial masyarakatnya, ekonomi, pendidikan maupun pariwisata. Hal ini terjadi berdasarkan pemaparan sebelumnya. Dengan demikian Komunitas Red Batik khususnya dan komunitas-komunitas lain pada umumnya, memiliki peran yang cukup penting. Sama halnya dengan yang diungkapkan oleh Heru Prasetya bahwa, "kalau kota ini penuh kegiatan-kegiatan yang kreatif, event-event yang kreatif, juga gagasan-gagasannya yang luar biasa, otomatis pariwisata akan punya dampak, kunjungan wisatawan dan sebagainya. Jadi kalau kota ini tanpa ada kreatifitas komunitasnya, mungkin tidak ada kegiatan apa-apa, karena memang hampir semua kegiatan di Kota Solo dilahirkan dari komunitas, sedangkan pemerintah hanya 
mendukung sebenarnya dan ini yang menjadi sangat penting".

Komunitas Red Batik seperti ruang ekspresi pendidikan informal bagi kaum muda, yang mungkin dalam menjalani proses kreatif itu mereka tidak mendapatkannya di bangku pendidikan formal. Dengan demikian kreativitas ruang informal Komunitas Red Batik bisa melengkapi kreativitas yang dijalani di bangku pendidikan formal. Dengan adanya workshop-workshop yang diadakan, membuat masyarakat lebih mendekatkan diri kepada pasar tradisional, hingga terciptanya sebuah karya menjadikan sebuah sajian menarik sebagai hiburan yang patut di ditontonkan dengan begitu banyaknya pembelajaran yang bisa diambil. Komunitas Red Batik turut memajukan Kota Solo, mulai dari budaya, pendidikan dan juga pariwisatanya serta mendorong atau mendukung terciptanya Kota Solo sebagai Kota Kreatif.

\section{SIMPULAN DAN SARAN}

\subsection{Simpulan}

Dari hasil penelitian yang telah dilakukan dapat ditarik kesimpulan komunitas memiliki peran penting dalam pembangunan pariwisata, dilihat dalam CBT. Dalam mengembangkan sebuah destinasi wisata dengan memberdayakan masyarakat (komunitas) memiliki peranan yang sangat penting.

Komunitas Red Batik didirikan pada 12 Februari 2011 dan di koordinasi oleh Heru Prasetya. Komunitas yang beralamat kantor di Jalan Jawa 18 Timuran Solo ini bergerak di bidang kostum dan karnaval. Komunitas Red Batik menggunakan pasar tradisional sebagai bahan atau kekuatan utama dalam berkarya. Kreativitas dihasilkan dari bahan-bahan alami yang dapat di temukan di pasar tradisional. Komunitas ini sering mengadakan agenda, pertunjukan maupun workshop di Kota Solo, namun selain itu juga telah ke berbagai daerah di indonesia dan luar negeri untuk tampil dalam suatu agenda yang ada maupun melakukan workshop untuk mengenalkan dan mengajarkan sebuah seni kreativitas.

Red Batik Solo Berdasarkan 10 prinsip kota kreatif, Komunitas Red Batik memiliki peran atau berkontribusi 6 dari 10 prinsip tersebut. Selain itu juga memberikan sebuah ruang untuk masyarakat dalam berkreativitas khususnya dalam bidang kostum dan karnival, dan membatu untuk menjaga dan melestarikan pasar tradisional yang merupakan ciri khas Kota Solo untuk terus ada diantara modernitas saat ini. Dengan adanya workshop yang diselenggarakan, terbentuknya sebuah kreativitas dan kemudian di gelarnya suatu event, atau seni pertunjukan mampu meningkatkan sumber daya manusia, ekonomi masyarakat dan meningkatkan kemajuan pariwisata Kota Solo.

\subsection{Saran}

Berdasarkan hasil tersebut, maka saran yang dapat diberikan sebagai berikut:

(1) Untuk Pemerintah, diharapkan pemerintah lebih memerhatikan, mendukung dan memberikan arahan terhadap komunitaskomunitas yang ada di Kota Solo. Dengan selarasnya masyarakat lokal (komunitas) dan pemerintah, maka agar nantinya pariwisata Kota Solo dapat berkembang mengalami peningkatan dan sukses terwujudnya Kota Solo sebagai Kota Kreatif.

(2) Bagi Komunitas Red Batik, untuk lebih sering mengadakan workshop sehingga makin banyak masyarakat yang turut berpartisipasi, serta mengadakan acara bulanan/ per dua bulan sehingga wisatawan tidak harus menunggu 1 tahun dua kali.

(3) Bagi Masyarakat, agar lebih berkontribusi lagi dalam industri maupun kegiatan kreatif, sehingga aspek ekonomi kreatif dan industry kreatif Kota Solo lebih terangkat lagi. Diharapkan peran serta masyarakat lebih besar, sehingga dalam mewujudkan Kota Solo sebagai Kota Kreatif dapat tercapai.

\section{DAFTAR PUSTAKA}

Febianti.2015. Memperkuat Citra Pariwisata Budaya: Denpasar Sebagai Nominasi Jaringan Kota Kreatif Unesco. Denpasar: JUMPA

Henry, Colette \& Anne de Bruin. 2011. Entrepreneurship and The Creative Economy. Cheltenham, UK: Edward Elgar Publishing

Hermantoro, Henky. 2011. Crative-Based Tourism. Cinere Depok: Aditri

Landry, Charles \& Franco Bianchini. 1995. The Creative City. London: Demos

Sandjaja, B dan Heriyanto, Albertus. 2006. Panduan Penelitian. Jakarta: Prestasi Pustaka

Saputro, Yulianto Wahyu. 2015. Tahapan Perwujudan Kota Surakarta Sebagai Kota Kreatif Desain. Yogyakarta: Universitas Gadjah Mada (Skripsi) 
Vol. 7 No 1, 2019

Setyawan, Arif Budi. 2013. Pengembangan Kota Solo Sebagai Kota Wisata Kreatif. Surakarta: Universitas Negeri Sebelas Maret (Skripsi)

Sugiono. 2010. Metode Penelitian Kuantitatif Kualitatif. Bandung: Alfabeta

UNESCO: Creative Cities Network

Yoeti, Oka A. 1996. Pengantar Ilmu Pariwisata. Bandung: Angkasa

\section{Sumber Lain:}

antaranews.com/berita/525074/solo-dijadikanpercontohan-kota-kreatif-indonesia/ (diakses pada tanggal 6 juni 2016)

http://www.unesco.org (diakses pada tanggal 6 juni 2016)

http://www.wiracana-handfan.com/ (diakses pada tanggal 6 juni 2016)

m.okezone.com/read/2016/03/15/470/1336824/begini10-prinsip-kota-kreatif (diakses pada tanggal 6 juni 2016)

Sutrisnoutomo.wordpress.com/2012/03/05/pariwisataberbasis-komunitas (diakses pada tanggal 20 juni 2016)

www.landasanteori.com/2015/10/pengertian-peranandefinisi-menurut.html? $\mathrm{m}=$ (diakses pada tanggal 20 juni 2016) www.materibelajar.id (diakses pada tanggal 20 juni 2016) www.redbatiksolo.weebly.com (diakses pada tanggal 20 juni 2016) www.sccn.or.id/news/konferensi-kota-kreatifindonesia.html (diakses pada tanggal 20 juni 2016) 